\title{
Playing Global Monopoly in Cement: The Globalization of CEMEX
}

\author{
Mark William Cawman \\ School of Business and Management, Azusa Pacific University \\ 901 East Alosta Avenue, Azusa, California 91702, United States \\ Tel: 1-626-815-6000 x 3091 E-mail: mcawman@apu.edu
}

Patricia Fine-Skalnik

School of Business and Management, Azusa Pacific University

901 East Alosta Avenue, Azusa, California 91702, United States

Tel: 1-626-815-6000_E-mail: pskalnik@apu.edu

\begin{abstract}
Received: December 2, 2020 Accepted: February 6, $2021 \quad$ Published: February 12, 2021
doi:10.5296/csbm.v8i1.18296ＵRL: https://doi.org/10.5296/csbm.v8i1.18296
\end{abstract}

\begin{abstract}
This research article is intended for use as a classroom case study with questions for discussion in International Business. This research analyzes CEMEX and their strategy for globalization. CEMEX is a Mexico founded building materials company that operates in more than fifty countries and maintains trade relationships in over one-hundred nations. In addition to CEMEX creating an international business, CEMEX embraces core values including ethics, integrity, and environmental sustainability. The literature review in this study, documents how CEMEX overcame cultural and political implications, and significant risk to become a significant multinational corporation. The topical focus and purpose of this research is to explore CEMEX critically as a specimen company representing cross-cultural and international business growth. The analysis includes the utilization of the Hofstede Cultural Dimensions framework and the PESTLEEG analysis.
\end{abstract}

Keywords: CEMEX, International business, Culture, Globalization, Strategy, Hofstede cultural dimensions, PESTLEEG, Patrimonio Hoy 


\section{Introduction}

CEMEX Sociedad Anónima Bursátil de Capital Variable incorporated as CEMEX S.A.B. de C.V. and herein referred to, as "CEMEX" or "Cemex", is a Mexico-founded, building materials company that operates in more than fifty countries and maintains trade relationships in over one-hundred nations and with annual revenues of \$13,130 Million USD in 2019 (CEMEX, 2020). In addition to CEMEX creating an international business, CEMEX embraces core values including ethics, integrity, and environmental sustainability. CEMEX is an example or case study of globalization in business, and this research report includes analysis of the CEMEX challenges, opportunities, and strategies with globalization and cross-cultural theories.

CEMEX was chosen for a case study, as it is an academically viable company for exploring globalization theories, as there is a reasonable amount of literature available already in the scholarly community. Some of the literature review referenced in this research article examines the risk, marketing strategies, and some of the tools and theories that made CEMEX successful, as well as some of the decisions that have created challenges for CEMEX. Lessard and Lucea (2008) agree that CEMEX is a relevant example and model for multi-national corporations to study (p. 3). CEMEX has continued to be a relevant example, even as they have addressed COVID-19 in 2020. This case study/article is a composite of literature review and critical analysis, using several traditional business evaluation tools (e.g., Porter's five forces, and Strength, Weakness, Opportunity, and Threat or 'SWOT' analysis). Additionally, the strategy includes globalization analysis methods of a Political, Economical, Social-cultural, Technological, Legal, Ethical, Environmental, and Geographical / Demographical or 'PESTLEEG.' analysis (Cawman \& Liu, 2020) - expanded from PEST / PESTEL models; and the Hofstede Cultural Dimensions framework (Hofstede, Hofstede, \& Minkov, 2010).

\section{History and Growth}

Founded in 1906 in northern Mexico, CEMEX, S.A. de C.V. was dedicated to producing and commercializing cement. They grew domestically in Mexico between 1906 and 1990, largely through organic growth and acquisitions of smaller competitors (Lessard \& Lucea, 2009). Early international business endeavors were through exports of cement and clinker (e.g., the main calcinated ingredient in cement), with exports reaching 574 thousand tons annually in 1985, and through jointly investing with North American cement companies, CEMEX consolidated export programs in 1986 (CEMEX, 2014, History). By the year 1989, CEMEX was one of the ten largest cement companies in the world. CEMEX formed and utilized their first post-merger integration team in 1987, which gained them experience and structure for all non-organic growth since. Some political landscape changes coupled with CEMEX's risk tolerance and foresight deserve credit for CEMEX moving beyond their domestic borders. Mexico's free-market shift allowing Foreign Direct Investment (FDI) and Mexico entering into the North American Free Trade Agreement (NAFTA) were part of the environmental shift that provided CEMEX with new market horizons. CEMEX responded to this opportunity as an early adopter, capitalizing on the external opportunity by employing a 
couple of their greatest strengths. Lessard and Lucea (2009) describe these strengths of CEMEX as some experience and risk perception, “...having "grown up" in one of the world's tougher market and institutional environments in the world, CEMEX developed the ability to thrive in markets where more powerful competitors dared not go (p. 300). The second pervasive theme is managing risk not as something independent of, but as, the day-to-day business of the company. Risk management is so embedded in the company culture and organizational fabric that it is barely noticeable as a distinct management function at either the strategic or tactical level" (p. 301). The ability to innovate began in CEMEX's roots back to 1920 , when the plants first kiln developed and used the long single-step drying process for cement, which was deemed as modern technology of its time (CEMEX, 2020).

This company value has been continued, enabling the ability to thrive in the tough market of Mexico, requiring additional innovative systems (Chung, Paddack, \& Marchand, 2003) and marketing (Dawar \& Frost, 1999; Lessard \& Lucea, 2008) for CEMEX. The innovative systems that CEMEX has and is using include excellent IT systems for logistics and information (Chung, et. al., 2003). This IT strength began in 1987 with the launch of a company-wide satellite communications system, CEMEXNet, and added an in-house IT logistics system Neoris, in 1993 (CEMEX, 2014). More recently, CEMEX has launched the "CEMEX Go" application for orders and payments online to facilitate safely distanced transactions for COVID-19 considerations (CEMEXUSA, 2020).

Illustrative of CEMEX's ability to innovate, take risk, and to adapt to environments is their 1998 development of the "Patrimonio Hoy" project (Sandovol, 2005; Sanchez, \& Ricart, 2010). Shifting strategically from a business-to-business strategy to a business-to-consumer strategy, this strategy provided a layaway financing and technical support, with the result of a large DIY (do it yourself) market for cement, concrete, and aggregate products (Sanchez, Ricart, \& Rodriguez, 2005). Not only did this create a market, but it also enhanced the CEMEX brand as a company with more "value-added" offerings by including these services, and created societal value in its home market (Laszlo, Sherman, Whalen, \& Ellison, 2005). This innovative way to sell concrete to low-wage workers in Mexico, created a globalization model for finding markets in underdeveloped nations and neighborhoods previously not considered viable (Prahalad, 2005). This domestic strategy is actually foundational for creating some globalization opportunities for CEMEX, and their international strategies build on their domestically tried strengths (Dawar \& Frost, 1999; Lessard \& Lucea, 2008). Columbia, Nicaragua, Venezuela, Costa Rica have embraced the Patrimonio Hoy project (Goldsmith, 2011; Hall, 2007) and evidence this adaptability to globalization.

The management of CEMEX took advantage of some of the political changes occurring in the 1990s including Mexico's free-market shift allowing foreign direct investment (Ghemawat, 2007; Lessard \& Lucea, 2009), and acquired two large Spanish cement producers in 1992 - Valenciana and Sanson (CEMEX, 2014). This acquisition "allowed CEMEX to shift its financing from short-term Mexican peso debt to longer-term Spanish peseta debt" (Dawar \& Frost, 1999). Dawar and Frost also note that CEMEX lowered its cost of capital by going public on the New York Stock Exchange. CEMEX is listed on the Mexican Stock Exchange ticker: "CEMEX. CPO" and the New York Stock Exchange ticker: 
"CX" (CEMEX, 2014). The acquisition of the Spanish companies was a strategic, opportunistic, and economic move. This move took advantage of the political freedom to restructure capital, moved into the backyard of a global competitor (e.g., France's Lafarge), and reduced CEMEX's dependence on the volatile domestic (Mexico) cement market (Dawar \& Frost, 1999). Between the years of 1994 and 1996 CEMEX completed acquisitions that positioned them in Central and South America, the Caribbean, and the United States moving them up to be the third largest cement company in the world. The years from 1997 through 2004 included further globalization as they entered the Philippines, Egypt, and Thailand. In 2005, CEMEX doubled their size through the acquisition of the RMC Group (an England based company) and gained markets throughout Europe. In 2007, CEMEX acquired Rinker and had operations in Australia. CEMEX continued building on their strengths (Ghemawat, 2007; Ghemawat \& Matthews, 2000; Lessard \& Lucea, 2009; Prahalad, 2005) and making new acquisitions until they peaked at almost a fifteen-billion-dollar global corporation (CEMEX, 2014). CEMEX has accomplished growth through start-up investments, acquisitions, and organic growth driven by innovative business strategies. Azad (2009) suggests that a large reason that CEMEX is so successful at globalization through acquisitions is the standardized process they use in execution. They continue to refine and take lessons from each acquisition, providing a basis for a continual learning organization.

The globalization history of CEMEX would be a great story if it stopped in the year 2007 . Multiple business cases have studied the CEMEX model and the quick growth of the cement company from Mexico. In the last decade-plus though, there have been some issues. The acquisition of Rinker cost $\$ 16$ billion USD, and came immediately before the financial crisis of 2008 (Lopez \& Stargardter, 2014). CEMEX's growth experienced setbacks, and they have sold and traded portions of their portfolio for debt management or strategic alignments as evidence by the divesture of Australian operations to Holcim in 2009 (CEMEX, 2009; Holcim Australia, 2009). Continued acquisitions and expansions leveraged CEMEX and according to Lopez \& Stargardter (2014) by the end of 2013, CEMEX had \$16.3 billion USD in net debt. CEMEX's leverage ratio -- net debt to EBITDA was 6.2, which is well above the industry average. In 2019, the leverage ratio was approximately 4.7. Just as a point of reference the 20-year average for American companies in 2010 was 3.4 (Gilliland, 2008). CEMEX also had limited cash flow as they utilized cash to pay down debt. CEMEX (2014) published their year-end 2013 total debt at \$16,993 million USD, and their consolidated funded debt/EBITDA at 5.49\%. Lopez and Stargardter (2014), projected that this may limit CEMEX's ability to take advantage of significant opportunities for the near and foreseeable future. In 2018, CEMEX published a defined strategy of debt reduction, including the divesture of some assets (Harrup, 2018). By June of 2020, the total debt was down to \$13,638 million USD, and their consolidated funded debt/EBITDA at $4.57 \%$, so they have improved from their 2013 published position (CEMEX, 2020). Net Sales was down from the approximately 15-Billion-dollar peak to around 13 Billion (USD). In 2019, sales were 13,130 Billion. Their net debt was 9.1 Billion, EBITDA 1,919,864, resulting in a $4.74 \mathrm{debt} / \mathrm{EBITDA}$ comparison (YahooFinance, 11/20).

The gross profit margins have been stable at approximately 33\% between 2015 and 2020 . The 
current ratio has been consistent at about .85 , so they are able to pay the current liabilities with current funds. As confirmed prior, the debt-to-equity ratios decreased to 1.2 in 2020, from 2.18 in 2017. This was a result of CEMEX making divestitures of \$1,514 million, primarily in the U.K., Germany, Spain, Mexico, Brazil, and the U.S. (CEMEX, $2^{\text {nd }}$ Quarter Results, 2020).

\section{Values, Strategies, and Execution}

\subsection{Sustainability}

CEMEX has clearly stated values that include environmental and community sustainability, beginning early in its history. They have engaged in extra-curricular and philanthropic programs towards fulfilling their value agendas. In 1978, they implemented the use of dust filters and pre-heaters as improvements in their production processes (CEMEX, 2020). Most recently, some examples include their environmental interests evidenced in their work in the Nature Book series (CEMEX Nature Book Series, 2013) and their social responsibility and community programs, even building homes within the local communities (CEMEX, 2014). CEMEX (2014) has collaborated with BirdLife for nature conservation efforts, and CEMEX continues to win awards for corporate citizenship and environmentally sustainable programs. The United Nations included CEMEX in the UN Global Compact stock index, recognizing CEMEX for sustainable practices and stock performance. CEMEX introduced an awards system in 2012 with both the "Ecoperating Building Certificate" and the "Ecoperating Plus Certificate" to recognize construction "projects that save energy, water, and reduce the environmental impact associated to construction and buildings." CEMEX bestowed the first award of this kind in 2014 to Lucena to "certify the outstanding sustainable qualities of Lucena” CEMEX (2014). CEMEX essence is sustainability and through awards and involvement in the construction industry and communities around the world, and they are encouraging other companies toward sustainable solutions. Additionally, CEMEX is conducting innovation on the products themselves, and has just announced the launching of an environmentally friendly concrete (CEMEX, 2014). In 2020, CEMEX announced an ambitious strategy to mitigate climate change and already, CEMEX touts some significant progress, as they estimate a 7.5 million $\mathrm{CO}_{2}$ ton reduction / avoidance since 1990 and have contributed to over 850 "green building projects" (CEMEX, 2020).

\subsection{Risk}

Analysis of CEMEX's flexibility and creativity includes a higher than average risk tolerance, as evidenced by many of their globalization and business moves. CEMEX (2014) outlines their business strategic approach, "We are constantly evolving in order to become more flexible in our operations, more creative in our commercial offerings, more sustainable in our use of resources, more innovative in conducting our global business, and more efficient in our capital allocation" (CEMEX, 2014, about us | our approach). While globalization provides spatial arbitrage opportunity, Ghemawat (2007) points out the need for normalizing risk (p. 93 \& p. 189). While exchange rates, cultural complexities, political tensions, and significant debt were real risks that CEMEX encountered in globalizing historically, there were normalizing factors. CEMEX's willingness to work across borders reduced dependency risk 
involved with the volatile domestic (Mexico) cement market (Dawar \& Frost, 1999), and Ghemawat (2007) suggests that CEMEX is a good example of geographic pooling (e.g., locating around workers and/or customers where there is alignment) thus reducing operating risks (p. 94). Azad (2009) pointed out the standardized process they used in execution of acquisitions, capitalizing on each experience. Normalizers of risk for CEMEX also included their balancing very few start-up ventures (riskier ventures) with acquisitions (established entities). A number of the acquisitions had known markets and strengths, and the alignment actually mitigated risk. The acquisition of the cement producers in Spain, thus changing debt structures, is an example of this normalization (Dawar \& Frost, 1999).

Many individuals, firms, and countries failed to account for a financial crisis in contingency planning, and the economy downturn of 2008, was ill-timed for CEMEX considering the magnitude of the 2006 and 2007 acquisitions. An agency theory review may explain some of the CEMEX actions and risk implications (Eisenhardt, 1989, p. 65). Eisenhardt postulates that organizations are assumed to have uncertain futures (e.g., prosperity, bankruptcy, or somewhere in the middle), and according to the agency theory organizations, push these ramification limits and view decisions and uncertainty in terms of risk/reward trade-offs. CEMEX had experienced rewards for many of their decisions, and were playing for larger stakes. Another normalizing or mitigating factor can be the use of contingent contracts or contingent payouts in mergers and acquisitions. Performance provisions in original contracts can mitigate some risk for parties and/or the community or environment involved (Reuer, Shenkar, \& Ragozzino, 2004). Public records exist for the transaction and higher-level terms for an acquisition (e.g., Security and Exchange Commission or 'SEC' filings). These legal filings refer to other executable documents such as "Pursuant to the terms of the Merger Agreement" and while these lower level documents are not public, they are vehicles for risk mitigation that CEMEX has available in acquisitions through contingencies and contingency payout provisions. Additional risks include current legal proceedings, in addition to COVID-19. There was an initial disruption in production and related activities due to COVID-19, and the government temporarily halted operations. In April, 2020, CEMEX resumed production, in accordance with the Health Ministry of Mexico guidelines. Operations in the future could be negatively impacted if further COVID guidelines change (CEMEX, 2 ${ }^{\text {nd }}$ Quarter Results, 2020).

\subsection{Offerings, Marketing, and The Patrimonio Hoy Program - Adapted from Sandoval, 2005}

CEMEX's strategy has been to offer their customers a full service, or a value-added solution to building materials, instead of just selling cement. The credit lines and complimentary products and training have been part of this strategy. Kogut (1985) considers the value-added model when designing international strategies. Rather than spreading resources too thin, Kogut suggests identifying and pursuing specific functional areas should have a firm's resource attention, providing priorities for strategic synergy. This activity requires competitive and comparative advantage studies in a dynamic fashion. CEMEX has executed appropriately at micro levels locally, adapting to these competitive and comparative advantages. The Patrimonio Hoy project is a value-added and competitive advantage in some environments; while CEMEX is innovating with proprietary Ready-Mix solutions and 
launching environmentally friendly concrete to fit other market environments (CEMEX, 2014).

CEMEX utilized marketing, implementing branding strategies dating back to the 1920's, introducing the "Cemento Portland Monterrey" branded cement in northwestern Mexico (CEMEX, 2020). Later, they pursued strategic marketing. In the 1990's, Cemex was struggling, as were most Mexican companies. A significant currency devaluation resulted in the loss of more than one million Mexican jobs. The company realized that they needed to do something "different" to consider business opportunities that were currently missing. Management knew that being myopic would not help their situation. Myopia is a management term that "business as usual" results from not seeing business opportunities from a new perspective, and thus prevents the company to uncover and pursue business opportunities in a shifting marketplace.

This situation prompted Cemex to reevaluate their business model, and to become resourceful in conducting a comprehensive marketing research project, conducted similar to an anthropological field study. Hector Ureta, director for new market development from Cemex, was an urban planner by training. He recognized the market's potential and knew the company had to fundamentally change its business model to achieve new sales in struggling communities. Almost 50\% of Mexico's 110 million people live on under $\$ 2$ per day, and approximately $30 \%$ of the nation's workforce have no formal employment (e.g., their work does not provide a formal paycheck or withhold taxes). Irrespective of their "informal" status, this population is still a viable market, purchasing: fired mud bricks, iron rebar, and cement for its cinder-blocks. CEMEX was losing out on these sales - previously believed to be not profitable enough to pursue.

Ureta deployed the program by first understanding the Mexican culture. He then assigned ten professionals (e.g., architects, sales, and construction experts) to live directly in these poor areas for approximately a year. The team studied the tanda, a Mexican money-pooling informal scheme. Ureta saw a lack of trust, relative to experienced deception by various politicians and businesses. The team studied the "auto-construction" do-it-yourself home building that is typical across rural Mexico - residence of many low-income farmers. They found numerous cases where the tanda funds were used for priorities of community (e.g., sewer lines and drinking water) instead of supporting the people in building their own homes.

After observing the people's lifestyles - Ureta was able to frame a sustainable, ethical business that was a win-win proposition for the company and their customers. CEMEX introduced its version of the Patrimonio Hoy-Personal Property Today model, combining micro-lending and community money pooling. This helped low-income Mexicans build homes faster (access to funds) and better (using durable cement products). CEMEX was thereby exploring a new market segment, inspired by the academic model of: "The Fortune at the Bottom of the Pyramid," by University of Michigan professor C.K. Prahalad (Sandoval, 2005).

Sandoval (2005) notes that CEMEX offered a program to customers that afforded them a respectable way to realize their home-building dreams. They were able to pay about $\$ 14 \mathrm{a}$ 
week, for 70 weeks and have access to "consultations and inspections by CEMEX staff architects, and scheduled deliveries of materials divided into building phases that covers the 70 weeks" (Sandoval, 2005). Because CEMEX could use their own buying power, they could normalize market fluctuations and keep prices stable for the life of the project(s). CEMEX used word-of-mouth marketing within the communities and would pay recruiters to demonstrate how Patrimonio Hoy works. "When they see how fast their neighbors are building, and how nice the homes look, they want to join," Calixtro said. "And we make a show of delivering the materials to the home sites. The trucks of incoming materials have advertisements on them for Patrimonio Hoy" (Sandoval, 2005). In another quote Salazar states, "Because of the program, my family now has three homes under construction. We would never have done it so fast, and because the materials are more affordable, I'm building my home strong and better" (Sandoval, 2005). As a testament of the program deployed by CEMEX:

- Customers have materials on terms tailored to their situations.

- Over 99\% of materials CEMEX distributed (\$42 million at the time if Sandoval, 2005 research) is being paid for on-time.

- Patrimonio Hoy has sponsored the building of 10,000 homes in Mexico.

- A smaller project was launched in Columbia.

\subsection{Social-Cultural}

As CEMEX has conducted international business around the world, they have a stated value of improving the indigenous communities (CEMEX, Sustainable Development and Strengthening Communities, 2014), and they have seemingly been successful without hegemonistic collateral issues. Featherstone (1990) clearly defines different approaches to globalization, including some perceptions of a "global culture" or illustrations where globalization has been equal to an Americanization or Westernization. CEMEX has not pushed a "global culture" or a homogeneous solution in their international business engagements. They do demonstrate cosmopolitanism and "neoclassic tolerance" necessary for cultural acceptance. Von Bergen, Von Bergen, Stubblefield, and Bandlow (2012) describe three degrees of tolerance as classical tolerance (e.g., forbearance), authentic tolerance (e.g., respect) and neoclassic tolerance (e.g., acceptance, value, and appreciation). Note that "tolerance" may not semantically define inclusion and diversity as well as some other words, but this progression is understood as well-intentioned by the Von Bergen et. Al., research. CEMEX's relationships bridging cultures would not have flourished under classical tolerance -- such that they recognize a culture's right to existence and forbear or tolerate the culture. Where some of the attractiveness and romanticizing between two cultures does not exist, an authentic tolerance at least allows progress and business relationships to move forward through exercising civility, dignity, and respect. Business relationships flourish in this neoclassical tolerance, and the CEMEX values and results suggest neoclassical tolerance inclusion, diversity, and the value of all stakeholder's values and norms. Von Bergen et. al. (2012) defines neoclassical tolerance, “...neo-classical definition of tolerance asks citizens to be open-minded and empathetic toward a virtually endless parade of differences; it asks them to work sympathetically to build institutional and cultural arrangements that will 
accommodate different ways of life.....rather than a begrudging endurance implied in the classical definition of tolerance, the "appreciate differences" brand of tolerance (i.e., neo-classical tolerance) implies a duty to approve and embrace diverse beliefs, customs, and behaviors..." (p. 113).

Ghemawat (2007) suggests that CEMEX is a good example of geographic pooling (e.g., locating around workers and/or customers where there is alignment), and the limited dependency on expatriates or moving large constituents into international environments, helps to preserve the indigenous cultures. For those relocated into international assignments, the cosmopolitism that occurs does include the potential of hybrid or third culture creation (Featherstone, 1990, p. 11). Salientes-Narisma (2013) had a biographical article in the Philippine Daily Inquirer that chronicles Pedro Palomino's (President of CEMEX Philippines) experiences in moving his family from Spain's Canary Islands to the Philippines. The shared experiences with the people and the cultural sharing are testimony to the neoclassical tolerance and cosmopolitanism of CEMEX's leadership in international business.

\subsection{Ethics}

Much of CEMEX's success in working across borders in international business has been assuring the values of the business align with the community values in the environments in which they do business. Currently, CEMEX includes an ethos line, "We believe that ethical behavior is a key factor for our success" (CEMEX, 2020). This value alignment has also bridged many ethical dilemmas. Wines and Napier (1992) note that "ethics is the systematic application of moral principles to concrete problems" (p.1), and suggest that ethics can be unified across cultures if the attitudes and values that drive behaviors and perceptions are aligned. Certainly, there are challenges in cross-cultural applications and perceptions, and this communized approach seems at odds with the ethical dilemmas experienced in international business by many international business managers. Wines and Napier suggest that this is due to values alignment. When values differ, so do the behaviors that engage in the realization of those values. Values thus driven by attitudes and beliefs experience differences when there are heterogeneous attitudes and values, or attitudes and values that are geo-local centric. Business managers can manipulate value statements toward a common good (e.g., utilitarian) hybridized and yet a single and homogeneous values set. CEMEX has successfully distilled their values towards that which is utilitarian and universally acceptable (CEMEX, Sustainable Development and Strengthening Communities, 2014). In spite of the CEMEX emphasis on ethics and the fair practices they have emphasized in the communities where they do business, they also have had some issues. In 2016, CEMEX self-disclosed monies paid to the Columbian counterparty associated with acquisitions, rights, and tax benefits. They noted that they had uncovered a weakness in their internal controls over financial reporting (LaCroix, K, 2019, July 17). To support ethical practices and compliance, CEMEX has nine specific areas they support: ethics, governance, antitrust, anti-bribery, information retention, insider trading, conflict minerals, anti-money laundering, and third-party policies (CEMEX, 2020). 


\subsection{Politics}

CEMEX has taken advantage of political shifts, both in Mexico and throughout the world. In the early 1990s, Mexico's free-market shift allowed foreign direct investment and Mexico entered into NAFTA. Both of these environmental shifts provided CEMEX with new market horizons. CEMEX has run into legal and political limitations in acquisitions and divestures involving certain turnover thresholds or perceived monopoly creations. In October of 2013, the European Commission was investigating a portfolio restructuring between Holcim and CEMEX that involved CEMEX West (e.g., the western part of German operations) for turnover threshold issues (European Commission, 2013). In April of 2014, the European Commission is currently investigating CEMEX's plans to buy Holcim's Spanish operations, as there would be a potential monopoly created in Spain (Emmott, 2014). CEMEX has some insulation from political factors by the fact that they have acquired operations in various countries (FDI), as opposed to implied subjection to trade rules they would experience if they were strictly an export company. CEMEX has utilized arbitration and other means as necessary when there were legal or political issues. In 2008, CEMEX submitted a complaint for arbitration to the International Center for Settlement of Investment Disputes for CEMEX versus the Venezuelan Government. CEMEX noted in a press release on the subject that, "CEMEX has always been respectful of legally based sovereign decisions, as well as the legal and regulatory frameworks that exist within the countries in which it maintains an operational presence, but it has an obligation to its shareholders to defend its business interests" (CEMEX, Press Releases, August 20, 2008). Political regulations and decisions on exchange rates and taxes continue to be real opportunities and risks for CEMEX and are typical in investments abroad in international business.

\section{Strengths and Challenges}

CEMEX is a company recognized for demonstrating leadership and examples of globalization and environmental sustainability. A current and significant challenge is the debt of the company (Lopez \& Stargardter, 2014) although that has improved over the last three years (Harrup, 2018; CEMEX, 2020). To appreciate some of the strengths and challenges of CEMEX, Figure 2 (SWOT Analysis) illustrates some of the internal and external factors. The internal implications for CEMEX are their strengths and weaknesses, and the external factors are the opportunities and threats.

\subsection{Internal Assessment}

CEMEX has an advantage, as their customer base is large. CEMEX supplies a bifurcated market that includes large commercial, infrastructural, and institutional programs, as well as small consumer and residential projects. Due to its shifting from a business-to-business model to a business-to-consumer model, CEMEX is not captive to a few customers with large orders, and the large and diverse market normalizes some risk and provides stability. The poly-geographical market also helps make cement and construction supplies more inelastic. This geographic diversity (a dynamic number, but in excess of fifty countries with trade relationships in over one-hundred nations) is also a strength that CEMEX has realized through its acquisitions and globalization. CEMEX has innovated in acquisition strategies, 
and systemized the process (Azad, 2009). A process manages the integration of acquisitions that CEMEX calls "CEMEX Way", as described by Lessard and Reavis (2009), "The CEMEX Way process involves the dispatch of a number of multinational standardization teams made up of experts in specific functional areas (Planning, Finance, IT, HR), in addition to a group leader...each team overseen by a CEMEX executive at the VP level...instead of eliminating the $80 \%$ [of the acquired company's practices as is typical in takeovers]...the CEMEX Way teams catalogued and stored those practices in a centralized database. Those processes were then benchmarked against internal and external practices. Processes that were deemed as "superior" ... became enterprise standards and, therefore, a part of the CEMEX Way" (Lessard \& Reavis, 2009, p. 6).

Lessard and Reavis's research found that the diligence in the CEMEX Way, has improved the integration times post acquisition or merger, from over 25 months to less than five months. Innovation has also included more than just acquisitional growth, and CEMEX has innovated with their organic growth as well as evidenced by their creating programs like Patrimonio Hoy. CEMEX has been innovative in the development of sustainable programs, new products, and production efficiencies. Capitalizing on its historical internal culture of innovation, cost efficiencies and environmental solutions, CEMEX continued its leadership in technology as they developed a satellite tracking system (e.g., CEMEXNet) for all their operations as early as 1987, and a complete IT logistics system (Neoris) in 1993. CEMEX continues to have a great strength in their IT systems and innovative logistical infrastructure, deploying CEMEX Go in 2019 (CEMEXUSA, 2020). CEMEX has over 100 years in the business of cement making, and is experienced at maximizing manufacturing efficiencies. One example of CEMEX's experience, innovation, and infrastructure in increasing cement plant efficiencies is the improvements seen in the facilities of CEMEX UK. Britain's RMC Group acquired by CEMEX in 2004 (CEMEX, 2014) experienced significant production efficiency gains in only a few years. CEMEX UK (2007) records realized efficiency levels of $95.4 \%$ with improvements by a $13 \%$ gain in a calendar year. CEMEX UK describes some of the production techniques and results, "Smart Silo is an automated system that allows monitoring of bulk cement silo stock levels. Built-in gauges and a processor device feed information from the silo to a computer system ensuring that deliveries are made on time to ensure continuity. 24/7 LOADTM is the new out of hours delivery service, easing pressures on congested sites and allowing customers to start the day with full silos of cement and/or bins of aggregate. It also helps reduce the risk of late deliveries by avoiding potentially heavy traffic at peak times" CEMEX UK (Press Release May 25, 2007).

CEMEX's risk tolerance is a considerable strength, when accompanied by normalizing factors (Ghemawat, 2007). In addition to acquisitions, CEMEX has engaged in R\&D -supported by nine laboratories under a collaborative network. In addition to concrete and asphalt technology, sustainability and energy management, patents, and pending applications are managed strategically (CEMEX $2^{\text {nd }}$ Quarter Report, 2020). CEMEX's aggressive globalization has been a trait that many consider a great strength (key strength in SWOT analysis).

An identified SWOT analysis weakness is the debt or leverage that CEMEX has accumulated. The significant spending in acquisitions peaked as the recession hit the global construction 
industry in 2008 (Lopez \& Stargardter, 2014). CEMEX and Holcim have traded and are trading companies and regions, as CEMEX attempts to balance its portfolio. The most significant weakness that CEMEX faces immediately is the significant debt. Heavily leveraged, a number of CEMEX's current moves are incumbent to the debt picture rather than market strategies. One other weakness that CEMEX faces is the seasonal aspect of their business. Some geographic regions experience winter recessions in the construction industry, while others face wet or rainy seasons that hamper all work relating to the cement and construction industry.

\subsection{External Assessment}

CEMEX continues to have many global opportunities. The Patrimonio Hoy model postures CEMEX in a unique position to market to the "bottom of the pyramid", or to emerging economies (Prahalad, 2005). This model opens up large markets that many companies would not even see as viable or equitable. With a significant portion of the world's population still impoverished or in emerging economies, CEMEX's experience, business model, and offerings allow this market to be open to them. The increased trend of globalization and allowance for free trade politically, has also afforded CEMEX opportunity. CEMEX has protected their image in globalization through sustainable solutions to environment and communities. This brand or image that CEMEX has fostered continues to gain opportunities and can give them invitations into less cosmopolitanistic environments as they are not viewed as hegemonistic. Because CEMEX is in a number of countries, there is opportunity to take advantage of unique country's trade regulations to capitalize on import and export opportunities. Table 1 shows significant import markets for cement, and production capacities could be flexed in countries with favorable trade regulations as an export opportunity. The emerging economies not only offer favorable labor markets, but also offer a significant sales market opportunity, as these economies are developing their infrastructure through construction projects.

Table 1. Top 5 Import / Export Nations of Cement (billions \$USD)

\begin{tabular}{|c|c|c|c|c|c|c|}
\hline & Country & Import 2011 & Import 2012 & Export 2011 & Export 2012 & $\begin{array}{l}\text { Import \% Export \% } \\
\text { of World of World }\end{array}$ \\
\hline \multirow{5}{*}{ 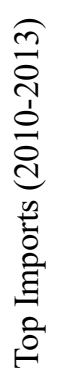 } & USA & $\$ 573,704,555$ & $\$ 635,212,680$ & $\$ 252,699,105$ & $\$ 312,670,355$ & $7.20 \%$ \\
\hline & France & $\$ 480,932,341$ & $\$ 448,922,474$ & $\$ 121,405,273$ & $\$ 132,517,080$ & $5.10 \%$ \\
\hline & Algeria & $\$ 133,535,180$ & $\$ 260,960,061$ & $\$ 6,613,403$ & $\$ 2,283,029$ & $3.00 \%$ \\
\hline & Nigeria & $\$ 411,490,108$ & $\$ 149,775,755$ & $\$ 1,546,244$ & $\$ 369,048$ & $3.00 \%$ \\
\hline & Sri Lanka & $\$ 345,369,287$ & $\$ 399,080,046$ & $\$ 30,164$ & $\$ 44,473$ & $2.80 \%$ \\
\hline
\end{tabular}




\begin{tabular}{cllllll}
\hline Macrothink & & \multicolumn{2}{c}{ Case Studies in Business and Management } \\
ISSN 2333-3324 \\
2021, Vol. 8, No. 1
\end{tabular}

Cement (Portland, aluminous, slag or hydraulic) + Hydraulic cements except Portland or aluminous. Developed from data obtained from UN Comtrade: United Nations Statistical Division. (2014) for periods 2011 \& 2012. Data retrieved April 23, 2014, from http://comtrade.un.org/

China provides an example of this market as they have been the fastest emerging economy (Table 2). In Table 2, China manufactures $59.3 \%$ of the world's cement while in Table 1, China only accounts for $5.6 \%$ of cement exports to the rest of the world. The conclusion is that China, during the period of emerging as an economy, has become the single most significant market and user of cement. Emerging economies are a significant opportunity for cement markets, and CEMEX's opportunity may follow the BRICS ("BRICS" is an acronym meaning Brazil, Russia, India, China, and South Africa. These five countries have projections to be the fastest growing emerging economies, and the best countries for outsourcing between now and the year 2050) (O'Neill, 2011). Brazil, Russia, India, and China were all in the top 10 world producers of cement (Table 2) and collectively equate to $66 \%$ or two-thirds of the world's cement production.

Table 2. Hydraulic Cement | World Production by Country - Top 10 Countries Plus the 3 Countries Needed for Exercise in Part 2

\begin{tabular}{lllllll}
\hline Country & 2009 & 2010 & 2011 & 2012 & 2013 & $\begin{array}{l}\text { Percent of } \\
\text { World } 2013\end{array}$ \\
\hline China & $1,644,000$ & $1,822,000$ & $2,099,000$ & $2,210,000$ & $2,416,000$ & $59.3 \%$ \\
India & 205,000 & 220,000 & 250,000 & 270,000 & 280,000 & $6.9 \%$ \\
USA & 64,843 & 67,202 & 68,639 & 74,934 & 77,415 & $1.9 \%$ \\
Iran & 50,000 & 61,000 & 66,000 & 70,000 & 72,000 & $1.8 \%$ \\
Turkey & 53,973 & 62,737 & 63,405 & 63,879 & 71,337 & $1.8 \%$
\end{tabular}




\begin{tabular}{lllllll} 
Brazil & 51,748 & 59,118 & 64,093 & 69,323 & 69,975 & $1.7 \%$ \\
Russia & 44,266 & 50,400 & 56,200 & 61,700 & 66,400 & $1.6 \%$ \\
Vietnam & 48,810 & 55,801 & 58,271 & 55,531 & 58,000 & $1.4 \%$ \\
Japan & 54,800 & 51,526 & 51,291 & 54,737 & 57,400 & $1.4 \%$ \\
Saudi Arabia & 46,000 & 47,500 & 50,700 & 56,200 & 57,000 & $1.4 \%$ \\
Philippines & 14,865 & 15,900 & 16,063 & 18,907 & 20,150 & $0.5 \%$ \\
South Africa & 11,784 & 10,870 & 11,234 & 11,560 & 12,200 & $0.3 \%$ \\
Australia & 9,200 & 8,300 & 8,600 & 8,600 & 8,400 & $0.2 \%$ \\
Total World & $3,054,818$ & $3,292,427$ & $3,651,075$ & $3,826,003$ & $4,074,446$ & $100 \%$ \\
\hline
\end{tabular}

Developed from Steinweg (2008) and Hydraulic Cement: World Production by Country (Index Mudi, 2015) and reported in thousand metric tons.

Another opportunity that CEMEX has is their image, emphasis, and programs for sustainable solutions. Chen (2009) correlates environmental actions and resulting satisfaction with brand equity. CEMEX has postured themselves as a sustainable company, and this is timely. Global consideration of environmental impacts includes construction and green building will continue to see rapid expansion with "some 90 countries on all continents now having [sic] nascent or established green building organizations" (Sustainable Business News website, 2013). CEMEX may win contracts, attract customer loyalty, or have politically favorable business considerations that involve the image of sustainability in environmental and community programs.

CEMEX is vulnerable to a number of threats, trends, or events. The continual sluggishness of the global economic recovery along with the COVID-19 pandemic, especially affecting construction sectors, threatens growth forecasts. Political events and unrest around the world create tensions when working across international borders. Trade agreements can change with administrations or events, as is evident with the current sanctions on Russia. When a company has investments in a country that experiences sanctions, that company or firm is threatened. The current sanctions (or threatened sanctions) against Russia and the resulting impact on American companies (e.g., General Electric and Boeing) is a good example (Lund, 2014). In addition to the economic and political threats, CEMEX has a relatively simple product with very few patents, and little Intellectual Property (IP) protection. Legal suits are a potential risk. As CEMEX continues to innovate, and with the release of a few of the new sustainable products there can be some mitigation of this threat, but a lack of IP protection is a threat.

Overall, as illustrated in the SWOT analysis (Figure 1), CEMEX has many identified strengths but they are heavily leveraged (internal factors). The opportunities are significant, especially in the emerging economies and at the bottom of the pyramid, marginally threatened by economic, political, and intellectual property considerations (external factors). 


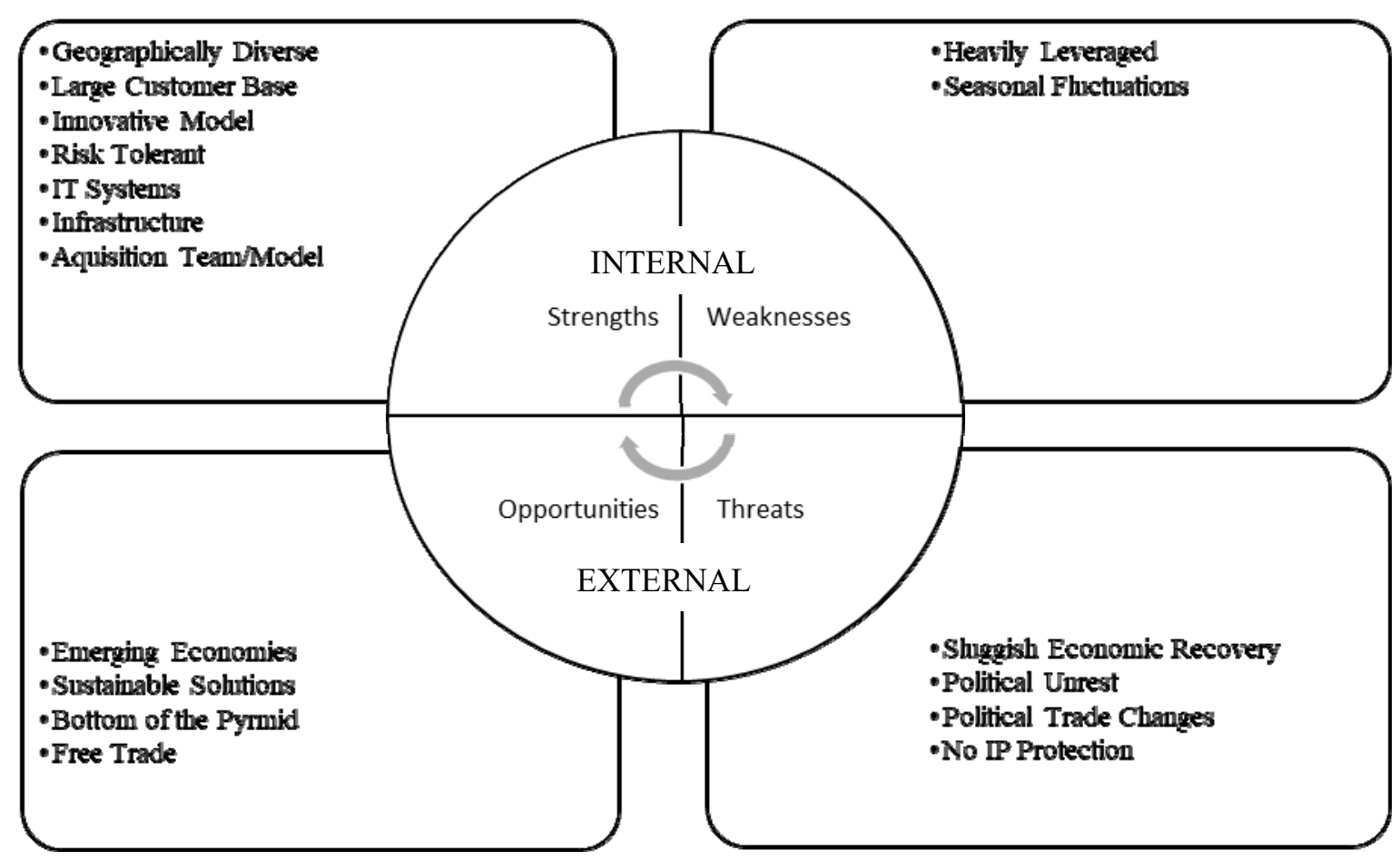

Figure 1. Strength, Weak

ness, Opportunity, and Threat (SWOT) Analysis

SWOT Analysis for CEMEX, based on the literature review and company analysis.

A further review of CEMEX using a Porter's Five Forces Analysis (Figure 2), highlights a few other strengths and weaknesses of the CEMEX model and/or cement industry. CEMEX has utilized an average of $93 \%$ local or national suppliers in their overall supply base for their production, and have supplier diversity. It is unlikely that CEMEX would have production or price interruptions resultant from supplier actions. Because of the acquisition model of large cement conglomerates, the competition in most of the environments is relatively territorial. CEMEX maintains some business model and process differentiation, but substitutionary threats exist, and they rank as the fifth largest cement company in the world in 2020 (Datis Export Group, 2020). 


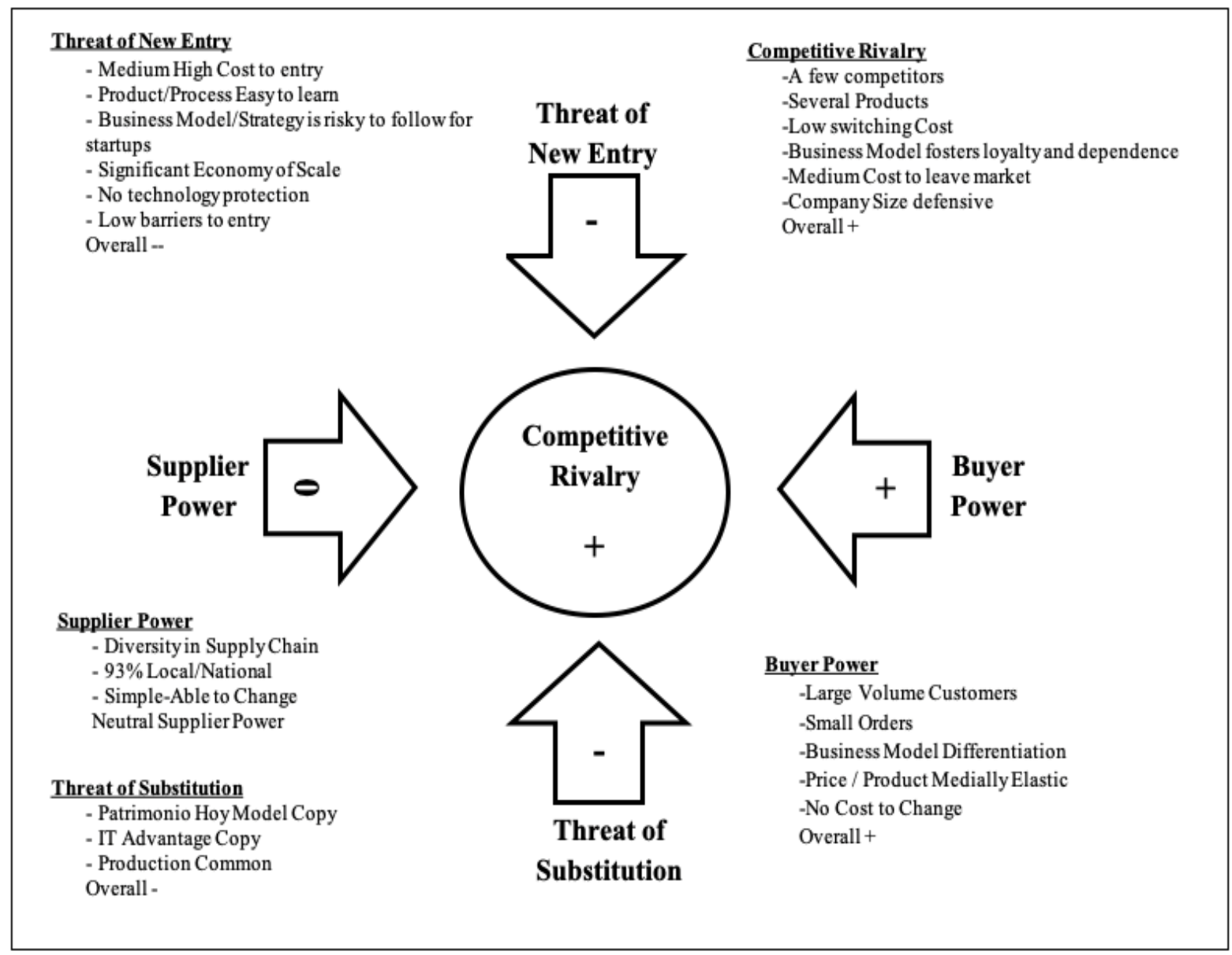

Figure 2. Porter's Five-Forces Analysis

Porter's Five Forces Analysis for CEMEX, based on the literature review and company analysis.

\section{Summary}

The significant growth and globalization of CEMEX over the last $\sim 20$ years is intriguing as a model of globalization. The CEMEX Way (Lessard \& Reavis, 2009) should be a benchmark for industries integrating acquisitions in a global context. CEMEX's ability to achieve results from acquired companies and to continually improve their model through best practices and lessons learned from acquisitions is one of their foundational strengths worth consideration in international business models. CEMEX continues to find ways to add value to their offerings, and had developed a reputation of excellence in living out their sustainable values. Industries investing in foreign markets or conducting international business, should study the image and offerings that CEMEX brings to other countries, and how they adopt or integrate the local values.

This research article analyzed CEMEX and their strategy for globalization. The results of this research substantiate how CEMEX overcame cultural and political implications, and significant risk to become a significant multinational corporation, but also speak to the resultant debt ramifications CEMEX faced, but also their recent stewardship actions to reduce 
this debt burden. CEMEX (as a specimen company representing cross-cultural and international business growth), has developed infrastructure and systems that businesses should emulate for successful acquisitions in a global context. Companies with more complex, technical, or culturally based product recognition or demand, may have to adjust the CEMEX model, but there is still a lot to learn from CEMEX. While being effective globally, CEMEX has also adopted the "think global, act local" model of tending to smaller, niche markets as reflected in their Patrimonio Hoy Program. If a cement company from Mexico can become a multinational conglomerate in a little more than a decade, a number of their systems and strategies merit further study and emulation. CEMEX is playing the game of monopoly in cement, and is postured to win.

\section{Part 2: A Case Study of Three Countries}

\section{Target Selection}

To understand the globalization successes of CEMEX better, three target countries are theoretically considered for globalization. CEMEX acquired Rinker in 2007, which included operations in Australia. CEMEX executed the divesture of Australian operations to Holcim in 2009 and traded portions of their portfolio for debt management or strategic alignments (CEMEX, 2009; Holcim Australia, 2009). Australia is a country that CEMEX sought (historically) to do international business in through acquisition and is included in this three-country case study. CEMEX has been in the Philippines for a number of years, and is expanding (CEMEX Philippines, 2013), partially due to the accelerating construction industry in the Philippines (The Philippines: Cementing Growth, 2013). The Philippines continues to be a very dynamic environment for CEMEX, and is included in this three-country case study. For the final country selected for this case study, the last member of the "BRICS" (e.g., South Africa) would be a new territory for CEMEX. The three countries analyzed thus include a past (Australia), present (Philippines), and potential target country (South Africa) for CEMEX globalization.

\section{Market and Demand}

In consideration of the market or business need in each target country, Table 1 shows a staggering 532\% increase from 2011 to 2012 in cement imported by the Philippines. During the same period, the Philippines only exported $18.6 \%$ of the volumes in 2012 that they did in 2011. In Table 2, year-over-year increases in domestic production are evident, but as an emerging economy with significant construction (The Philippines: Cementing Growth, 2013) there is significant opportunity for CEMEX to grow the domestic production, pacing with construction and offsetting the import increases. South Africa and Australia show a relatively consistent year over year production output domestically in In Table 2. Both of these countries have also seen import volumes increase and export volumes decrease (although not as significantly as the Philippines) in Table 1. The delta of import to export trends is suggestive of a demand for increased domestic production, and postures them as potential markets for a cement plant investment. Global Cement news headlines suggest several companies are actively considering investing in domestic cement plants for production in South Africa (Global Cement website, 2014). 
In 2020, CEMEX continues to be one of the largest cement companies in the world, based upon annual installed cement production capacity. They provide related services and reliable construction-related services to customers and communities and maintain business relationships in more than 50 countries throughout the world (CEMEX $2^{\text {nd }}$ Quarter Results, 2020).

\section{PESTLEEG Analysis}

In conducting an external assessment of the target locations using the PESTLEEG Model (Cawman \& Liu, 2020) [expanded from the PEST/PESTEL models], each location is to be considered for implications for globalization with several considerations, their impact, and the respective risk associated with each of the three target countries. After researching each PESTLEEG factor implication for each target country using data from some of the globalization agencies as shown in Table 3, analysis is possible by comparative consideration for risk / opportunity for each target location. Note that in the Economic factor, exchange rates must be considered (Fx-Exchange website, n.d.).

Table 3. Example Organizations and PESTLEEG Alignment in International Business

\begin{tabular}{ll}
\hline Organization or Resource & PESTLEEG Factors \\
\hline World Trade Organization (WTO) & Legal, Ethical \\
World Bank (WB) & Economical, Technological, Environmental \\
International Monetary Fund (IMF) & Economical, Ethical \\
United Nations (UN) & Political \\
Hofstede Cultural Dimensions-Country Comparisons & Social-Cultural \\
\hline
\end{tabular}

Adapted from: Cawman \& Liu, 2020 (Table 2).

\section{Cultural Analysis}

In establishing the PESTLEEG analysis for the social-cultural factors, a Hofstede Cultural Comparison tool is useful (Hofstede Insights, 2020) to execute cultural comparisons of the target cultures versus Mexico, CEMEX's headquarters. By utilizing this tool to compare some cultural characteristic differences, the implications to engaging in the various countries in a social-cultural aspect can be evaluated. As an example, differences may factor into which cultures are content in communal habitations versus requiring their own housing. The size and number of housing construction projects, and the number of customers involved (individual level or community level) are considered significant in this globalization research.

\section{Group Breakout Activities}

\subsection{Group 1}

Using the Hofstede cultural dimensions comparisons, compare Mexico (company's HQ) to each of the three targets (Hofstede Insights, 2020). 
1) What do you think cultural differences have to do with "Patrimonio Hoy" viability in these locations?

2) What do you think the cultural comparisons have to do with globalization success in the Philippines and how will this affect South Africa?

3) Generally, after reading about CEMEX and the "Patrimonio Hoy" project - what has made CEMEX successful in bridging culture?

\subsection{Group 2}

Using resources identified in Table 3, research to answer the following:

1) What are the Economic, Political, and Legal risks of business in each of these three locations?

a. Lowest Risk / Largest Opportunity Country for these three considerations is?

b. Highest Risk / Least Opportunity Country is?

c. Is CEMEX in the right place (Philippines) or should they be in one of the other two?

\subsection{Group 3}

Using resources identified in Figure 3 and outside sources, research to answer the following

1) What Country poses the largest risk for Ethical Challenges and Why?

2) What Country poses the least risk for Ethical Challenges and Why?

3) Are there any Geographical/Demographical considerations for any of these target locations?

\subsection{Group 4}

Considering the overview in this CEMEX case, consider:

1) Does Market Economy, Command Economy, or Mixed Economy affect the viability of a program like "Patrimonio Hoy", and if so, in what ways?

2) Does Government (e.g., Socialism, Dictatorship, or Democratic) affect the viability of a program like "Patrimonio Hoy," and if so, in what ways?

\subsection{Group 5}

1) Considering this case, does a slowing globalization or slowing FDI globally present risk to CEMEX? - Why or Why not?

2) Does this riskłor lack of risk differ for these three targets? Explain.

3) What impact does COVID-19 have long-term for CEMEX and for these target locations?

\subsection{Group 6}

The case demonstrated a large Sustainability and Corporate Social Responsibility emphasis 
by CEMEX. Doing some outside research into values and norms of the target populations as a sample of CEMEX globalization,

1) Is this altruistic, or is this vital to their business economically and their growth strategy or is it both? Explain.

2) What are some key improvements CEMEX has done environmentally? Does this support ubiquitous value systems and represent the countries they go into, or is this targeting the values of investors? Explain.

\subsection{Group 7}

The case emphasized the CEMEX inclusion of local community values and Corporate Social Responsibility - avoiding hegemony and advocating for indigenous values. Doing some outside research into values and norms of the target populations as a sample of CEMEX globalization,

1) What has CEMEX done in the Philippines to be successful in keeping community?

2) What will they need to do in the other two target locations? Explain.

\subsection{Group 8}

The case emphasized the CEMEX operational efficiencies in their facilities.

1) How does this efficiency affect their ability to enter an emerging economy versus an industrialized economy?
a. Technology?
b. Labor?
c. Education?
d. Consider the three factors above, plus any additional factors. Explain.

\subsection{Group 9}

The case emphasized the prowess and skill of the acquisition team at CEMEX. Outline the approach, decision making criteria and some of the activities you think this team will use to implement for each of the following target locations:

1) Cement Production (Factories)

2) Aggregate Quarry (Gravel Pits / Mines)

3) "Patrimonio Hoy" (Program)

\section{Conclusion}

For the exercise, groups should come back and report out on your group's research or findings. In the game of monopoly that CEMEX plays in cement, what are your thoughts and recommendations as they select targets and continue to globalize? 


\section{Notes and Acknowledgements}

- Part Two and/or Study Questions may be held back and assigned in real-time, or kept/assigned with the case for advance preparation.

- The past, present, and potential acquisition targets are purely theoretical for the purpose of a case study exercise.

- The authors would like to thank the first class and faculty that used this case study and gave feedback - especially Rachel Sharpe-Bodell, DBA and Dr. Gustavo Del Rivero, PhD.

\section{References}

Australian Government Department of Foreign Affairs and Trade website. (n.d.). http://www.dfat.gov.au/issues/measures-against-corruption.html

Azad, F. (2009, April 8). The secrets of successful companies: Cemex [Yahoo Contributor Network]. Yahoo! Voices. Retrieved from http://voices.yahoo.com/the-secrets-successful-companies-cemex-2877420.html

Cawman, M. W., \& Liu, D. M. (2020). External factors and risk considerations: Applying the Institutional-based view of management. Academy of Strategic Management Journal, 19(4), $1-16$.

CEMEX (2009, October 1) CEMEX completes sale of Australian operations [Press release]. Retrieved from http://www.cemex.com/MediaCenter/PressReleases/PressRelease20091001.aspx

CEMEX. (2012, December 31). Worldwide locations. Retrieved February 10, 2014, from www.cemex.com/aboutus/worldwidelocations.aspx.

CEMEX. (2014). Stock information. Retrieved February 21, 2014, from http://www.cemex.com/InvestorCenter/StockInformation.aspx

CEMEX (2014). Sustainable Development and Strengthening Communities [website]. Retrieved April 26, 2014, from http://www.cemex.com/SustainableDevelopment/StrengtheningCommunities.aspx

CEMEX (2020). Debt information as of June 30, 2020. Retrieved September 28, 2020, from https://www.cemex.com/investors/debt-information\#navigate

CEMEX (2020). Sustainability [website]. Retrieved September 28, 2020, from https://www.cemex.com/sustainability/overview

CEMEX (2020). Timeline [website]. Retrieved September 28, 2020, from https://www.cemex.com/about-us/our-history

CEMEX (2020). $2^{\text {nd }}$ Quarter Results [website]. Retrieved November 23, 2020, from https://www.cemex.com/2ndquarterresults

CEMEX Nature Book Series. (2013). Sublime nature: Photographs that awe and inspire | 
$\begin{array}{llllll}\text { Nature } & \text { Book } & 2013 & \text { [Video } & \text { file] } & \text { Retrieved }\end{array}$ http://www.cemex.com/SustainableDevelopment/NatureBook2013.aspx

CEMEX Philippines. (2013, June 6). CEMEX invests P2.5 billion to hike output. Media Hub. $\begin{array}{llll}\text { Retrieved } & \text { February } & 21, & \text { from }\end{array}$ http://www.cemexphilippines.com/MediaCenter/news/News20130606_2.aspx

CEMEX UK. (2007, May 25). CEMEX UK announces performance improvements at all its cement plants [Press Release]. Retrieved April 24, 2014 from http://www.cemex.co.uk/cemex-uk-announces-performance-improvements-in-all-its-cementplants-in.aspx\#CEMEXUKAnnouncesPerformanceImprovementsinAllitsCementPlantsin

CEMEXUSA (2020). CEMEX-Go. Retrieved September 28, 2020 from https://www.cemexusa.com/go

Chen, Y. S. (2010). The drivers of green brand equity: green brand image, green satisfaction, and green trust. Journal of Business Ethics, 93(2), 307-319. https://doi.org/10.1007/s10551-009-0223-9

Chung, R., Paddack, K., \& Marchand, D. (2003). CEMEX: global growth through superior information capabilities. International Institute for Management Development.

Datis Export Group (2020) Top 10 cement companies in the world in 2020. [blog] https://datis-inc.com/blog/top-10-cement-companies-in-the-world-in-2020/

Dawar, N., \& Frost, T. (1999). Competing with giants: Survival strategies for local companies in emerging markets. Harvard business review, 77, 119-132.

Eisenhardt, K. M. (1989). Agency theory: An assessment and review. Academy of Management Review, 14(1), 57-74. https://doi.org/10.5465/amr.1989.4279003

Emmott, R. [edited by O'Donnell, J.], (2014, April 23). EU opens investigation into Cemex-Holcim deal in Spain [Press release]. Retrieved from Reuters website: http://www.reuters.com/article/2014/04/23/cemex-holcim-eu-idUSL6N0NF3WH20140423

European Commission. (2013, October 22). Mergers: Commission opens in-depth investigation into proposed acquisition of Cemex West by Holcim [Press release]. Retrieved from http://europa.eu/rapid/press-release_IP-13-986_en.htm

Federal Reserve website. (n.d.). http://www.federalreserve.gov/releases/h10/hist/dat00_sf.htm Featherstone, M. (1990). Global culture: Nationalism, globalization and modernity : a theory, culture \& society special issue. London: Sage Publications

Fx-Exchange website. (n.d.). http://usd.fx-exchange.com/php/exchange-rates-history.html

Ghemawat, P., \& Matthews, J. (2000). The globalization of CEMEX. Harvard Business School.

Ghemawat, P. (2007). Redefining global strategy: Crossing borders in a world where differences still matter. Harvard Business Press. 
Gilliland, T. (2010, August 17). How strong is corporate America's balance sheet? [Newsgroup comment]. Retrieved from MarketMinder website: $\mathrm{http}: / / \mathrm{www} . m a r k e t m i n d e r . c o m / a / f i s h e r-i n v e s t m e n t s-h o w-s t r o n g-i s-c o r p o r a t e-a m e r i c a s-b a l a n c$ e-sheet/b14e50c8-8ae3-42cb-b046-ee62a28051bb.aspx

Global Cement website.

(2014).

http://www.globalcement.com/news/itemlist/tag/South\%20Africa

Goldsmith, A. (2011). Profits and alms: Cross-sector partnerships for global poverty reduction. Public Administration \& Development, 31(1), 15-24. https://doi.org/10.1002/pad.585

Hall, C. (2007). Turning Point: Are Emerging Market TNCs Sensitive to Corporate Responsibility Issues. Journal of Corporate Citizenship, 2007(26), 30-37. https://doi.org/10.9774/GLEAF.4700.2007.su.00007

Harrup, A. (2018, July 26). Cemex plans more asset sales, debt reduction: Mexican company aims to speed up growth and return to investment-grade ratings. The Wall Street Journal.

Hofstede, G., Hofstede, G., \& Minkov, M. (2010). Cultures and organizations: Software of the mind. Revised and Expanded 3rd Edition. New York: McGraw-Hill

Hofstede Centre cultural tools: Country comparison [Data Analysis]. (n.d.). Retrieved April 24, 2014, from: http://geert-hofstede.com/countries.html

Hofstede Insights (2020) Country Comparison [website] Retrieved from https://www.hofstede-insights.com/country-comparison/

Holcim Australia (2009, October 1) Acquisition of Cemex Australia successfully completed [Press release]. Retrieved from http://www.holcim.com.au/about-us/latest-media-releases/latest-release/article/acquisition-ofcemex-australia-successfully-completed.html

Hydraulic Cement: World Production, \& By Country. (2015). Hydraulic Cement: World Production, By Country. Retrieved November, 2020, from http://www.indexmundi.com/en/commodities/minerals/cement/cement_t22.html

Intellectual Property Office of the Philippines website. (2013). http://www.ipophil.gov.ph/

International Labour Organization (2013) Global Wage Report 2012/13: Wages and equitable growth. Geneva, Switzerland. Retrieved from http://www.ilo.org/wcmsp5/groups/public/---dgreports/---dcomm/---publ/documents/publicati on/wcms_194843.pdf

Johnson, K. D. (2014, January 22). Corruption in the Philippines: Survey of business execs reveals 'mixed' findings [Press release]. Retrieved from The Asia Foundation website: http://asiafoundation.org/in-asia/2014/01/22/corruption-in-the-philippines-survey-of-business -execs-reveals-mixed-findings/

Kogut, B. (1985). Designing global strategies: Comparative and competitive value-added 
chains. Sloan Management Review, 26(4).

LaCroix, K. (2019, July 17). A Closer Look at FCPA-Related Securities Suits. The D\&O Diary. $\quad$ Retrieved 12/2/2020 from https:/www.dandodiary.com/2019/07/articles/foreign-corrupt-practices-act/a-closer-look-at-f cpa-related-securities-suits/

Laszlo, C., Sherman, D., Whalen, J., \& Ellison, J. (2005). Expanding the value horizon. Journal of Corporate Citizenship, 20, 65-76 https://doi.org/10.9774/GLEAF.4700. 2005.wi.00009

Lessard, D., \& Lucea, R. (2008). Mexican multinationals: Insights from CEMEX. https://doi.org/10.2139/ssrn.1289439

Lessard, D., \& Lucea, R. (2009). Embracing risk as a core competence: The case of CEMEX. Journal of International Management, 15(3), 296-305. https://doi.org/10.1016/j.intman.2009.01.003

Lessard, D. R., \& Reavis, C. (2009, March 5). CEMEX: Globalization “The CEMEX Way”. MIT Sloan Management, 09-039. Retrieved from https://mitsloan.mit.edu/LearningEdge/CaseDocs/09\%20039\%20CEMEX\%20\%20Lessard.p df

Lopez, G., \& Stargardter, G. (2014, April 8). Debt may deter Cemex as Lafarge, Holcim asset sale looms [Press release]. Retrieved from Reuters on CNBC: http://www.cnbc.com/id/101562928

Luiz, J. (2002). Small business development, entrepreneurship and expanding the business sector in a developing economy: The case of South Africa. Journal of Applied Business Research, 18(2), 53-68. https://doi.org/10.19030/jabr.v18i2.2115

Lund, W. (2014, April 3). Russia sanctions and U.S. investment: A silver lining? Daily Finance. Retrieved from http://www.dailyfinance.com/2014/04/03/russia-sanctions-and-us-investment-a-silver-lining/

Newham, G. (2013, December 13). Why is corruption getting worse in South Africa? [Press release]. Retrieved from ISS | Institute for Security Studies: http://www.issafrica.org/iss-today/why-is-corruption-getting-worse-in-south-africa

O'Neill, J. (2011). The Growth Map: Economic opportunity in the BRICs and beyond. Penguin.

Prahalad, C. (2005) The fortune at the bottom of the pyramid. Upper Saddle River, NJ, Wharton School Pub.

Reuer, J. J., Shenkar, O., \& Ragozzino, R. (2004). Mitigating risk in international mergers and acquisitions: The role of contingent payouts. Journal of International Business Studies, 35, 19-32. https://doi.org/10.1057/palgrave.jibs.8400053

Salientes-Narisma, C. (2013, July 29). Cemex PH president Pedro Palomino: Great job in a 
nice place at the right time [Press release]. Retrieved from Business Inquirer $\mid$ Philippine Daily Inquirer website: http://business.inquirer.net/135143/cemex-ph-president-pedro-palomino-great-job-in-a-nice-p lace-at-the-right-time

Sandoval, R. (2005). BLOCK by BLOCK. Stanford Social Innovation Review, 3(2), 34-37.

Sanchez, P., Ricart, J., and Rodriguez, M. (2005). Influential factors in becoming socially embedded in low-income markets. Greener Management International, 51, 18-38. https://doi.org/10.9774/GLEAF.3062.2005.au.00003

Sanchez, P., \& Ricart, J. (2010). Business model innovation and sources of value creation in low-income markets. European management review, 7(3), 138-154. https://doi.org/10.1057/emr.2010.16

Steinweg, T. (2008). Cement: Sector scan. SOMO, Amsterdam.

Sustainable Business News website.

https://www.sustainablebusiness.com/index.cfm/go/news.display/id/24456

The Philippines: Cementing Growth [Press release]. (2013, March 26). Retrieved from http://www.oxfordbusinessgroup.com/economic_updates/philippines-cementing-growth

United Nations Department of Political Affairs. (2014). Activities by region. Data retrieved April 24, 2014, from http://www.un.org/wcm/content/site/undpa/main/activities_by_region

United Nations Statistical Division. (2014). Data retrieved April 23, 2014, from http://comtrade.un.org/

Von Bergen, C. W., Von Bergen, B. A., Stubblefield, C., \& Bandow, D. (2012). Authentic tolerance: between forbearance and acceptance. Journal of Cultural Diversity, 19(4)., 111-11

Wines, W. A., \& Napier, N. K. (1992). Toward an understanding of cross-cultural ethics: A tentative model. Journal of Business Ethics, 11(11), 831-841. https://doi.org/10.1007/BF00872361

WIPO | World Intellectual Property Organization. (2013, June 7). http://www.wipo.int/wipolex/en/profile.jsp?code=ZA

World Bank (2014). Ease of doing business in Australia. Data retrieved April 24, 2014, from http://www.doingbusiness.org/data/exploreeconomies/australia/

Yahoo Finance (2020). Financial Statements, CEMEX, S.A.B. de C.V. (CEMEXCPO.MX) retrieved November 14, 2020.

\section{Glossary}

PESTLEEG: Political, Economical, Social-cultural, Technological, Legal, Ethical, Environmental, and Geographical / Demographical. 


\section{Copyrights}

Copyright for this article is retained by the author(s), with first publication rights granted to the journal.

This is an open-access article distributed under the terms and conditions of the Creative Commons Attribution license (http://creativecommons.org/licenses/by/4.0/). 